\title{
Social Capital, Networks and Interlocked Independent Directors: A Mexican Case
}

\section{Introduction}

This research concerns the interlocking directorates and their potential implications for corporate governance practices in Mexico. Recent banking failures have seriously brought into question both corporate governance frameworks generally and the protection of shareholders more specifically (Heemskerk \& Schnyder, 2008; Kirkpatrick, 2009; Shankar and Bhattacharya, 2011; Ionescu, 2011). The role of independent directors and interlocked directorates in relation to protection of shareholders especially minority shareholders have been widely researched and debated in the literature (Zattoni \& Cuomo, 2010; Conyon \& Muldoon, 2006). Nevertheless, these studies were predominately located in developed markets (Fama \& Jensen, 1983; Huse, 2005; Johnson, Daily, \& Ellstrand, 1996; Stiles \& Taylor, 2001). Interlocking boards and independent directors have critical importance in emerging economies given the high concentration of ownership and absence of institutional investors (La Porta et al., 1999; 2000; Berglof \& Claessens, 2006; Uddin \& Choudhury, 2008). Despite this, research is scarce in emerging economies with some exceptions (Lim \& Porpora, 1987; Peng et al, 2001; Ong et al., 2003; Silva et al., 2006; Salas-Porras, 2006). Mexico, one of the emerging economies, is our research site to investigate network of independent directors, its emergence and implications for corporate governance mechanisms.

For several reasons, the Mexican situation is particularly useful for developing our understanding of networks of directors. Mexico has recently undergone huge corporate governance reforms and has assimilated the corporate governance model proposed by the OECD. One of the main obligations imposed by the Code and the New Securities Law (Ley del Mercado de Valores, LMV) on publicly listed corporations is the inclusion of independent board members on the board of directors. The background to the OECD's 
prescriptions is that the previous governance model was inadequate for monitoring and controlling company affairs in the best interests of shareholders, especially minority shareholders. Strengthening corporate boards by using independent directors was seen as a panacea for corporate governance problems. The reforms present an opportune moment to investigate their implications for board structures in Mexican corporations.

Furthermore, certain preconditions are required in order for the OECD reforms to be moderately successful. Previous studies on corporate governance have identified a number of essential elements in governing corporations, including well-developed capital markets, professional bodies, democratic institutions and a justice system free from political influence (Hopper et al., 2009; Tsamenyi \& Uddin, 2008; Uddin \& Choudhury, 2008). Studies of UK and US settings have indicated that these institutions are independent but inextricably linked with each other (Chua \& Poullaos, 1993), while studies of emerging economies have often argued that they are politically charged and family oriented (Uddin \& Choudhury, 2008). Studies in Mexico and in other Latin American countries have also argued that institutions in these countries show similar traits (Chong and Lopez-de-Silanes, 2007; Santiago et al., 2009). Given the lack of well-developed institutions, the study of interlocking boards and the identification of powerful actors in Mexico raise potentially interesting questions and issues. Nevertheless, previous studies have not taken a systematic account of whether a pattern of interlocking boards does really exist in Mexico. Theoretical explanations of emergence of interlocked directorates are important given the serious consequences it has on corporate governance mechanisms. Surprisingly, previous studies on interlocked directorates in Mexico or elsewhere are devoid of theoretical explanations i.e. broader understanding of emergence of networks. This study fills this gap drawing on the Bourdieusian notion of social capital.

This study poses two empirical questions: does a pattern of interlocking boards exist in Mexico, and what positions do actors occupy in the network structure of interlocking 
boards in Mexico? Social network analysis (SNA) was adopted to determine the social relationships linking board members and corporations. Previous accounting studies have adopted this type of analysis to identify networks of accountants, standard setters and managers (Chapman, 1998; Richardson, 2009; Tichy et al., 1979). This study investigates networks of boards of directors. It links individuals with corporations and allows the production of spatial maps to visualize the network structure of interlocking boards (Freeman, 2004). The basic concepts of SNA will be presented later.

This study also aims to answer some theoretical questions: why do networks occur, and what are their implications for corporate governance practices? In order to provide further explanations, this study draws in particular on the Bourdieusian notion of social capital (Bourdieu, 1986; Bourdieu \& Wacquant, 1992). Bourdieu defines social capital as "the aggregate of the actual or potential resources which are linked to the possession of a durable network of more or less institutionalised relationships of mutual acquaintance and recognition - or in other words, to membership in a group - which provides each of its members with the backing of the collectively-owned capital, a 'credential' which entitles them to credit, in the various senses of the word. These relationships may exist only in the practical state, in material and/or symbolic exchanges which help to maintain them" (Bourdieu, 1986:248-9). As will be explained later, in our case, social capital is created by sharing different boards of directors. In other words, the ensemble of connections, contacts, relationships, friendships and obligations gives them the power to act in relation to the quality and quantity of their relationships, and of relationships with other board members and businesspeople. We wish to examine whether the network structure of interlocking boards in Mexico reveals the relational practices of board members and the social capital created by interlocking boards. This will also help us to understand the emergence of networks. 
The paper begins with a brief literature review of interlocking boards and an overview of the independence of directors in both Anglo-American and less developed countries. Detailed accounts of SNA are then provided, followed by an empirical section focusing on interlocking boards, relationships, networks and powerful actors. The discussion section, drawing on the notion of 'social capital', provides an account of why networks occur and how they perpetuate the current status of board impotency and corporate governance affairs in Mexico. The concluding remarks briefly presents the implications of networked directors on the effectiveness of governance and protection of minority shareholders and explains avenues of future research.

\section{Previous studies}

Studies of interlocking boards go back a century or more (Jeidels, 1905; Hilferding, 1910; Brandeis, 1914; National Resources Committee, 1939). According to Mizruchi \& Bunting (1981), the causes and consequences of interlocking boards have been a source of debate since the Pujo Committee identified interlocking as a problem of corporate concentration in the early twentieth century. However, critics of research into interlocking boards have argued that interlocking boards are largely irrelevant and that research on the interlocking network represents the dominance of method over substance (Stinchcombe, 1990, cited in Davis, 1996:154). Nevertheless, majority of the research found interlocking boards are extremely relevant because, through them, it is possible to trace the social embeddedness of corporate governance (Davis, 1986). Through their experiences on other boards, interlocking directors act as a conduit for social influences that create an informational and normative context - "an embeddedness" - for board decisions (Granovetter, 1985, cited in Davis, 1986:154).

Research on board interlocks focuses also on how board members serve as a means for political and ideological preservation of the interests of the capitalist class (Mariolis \& 
Jones, 1982; Ornsten, 1984). The likelihood that interlocking companies will be audited by the same public accountancy firm is partially explained by ties between client companies created by interlocking directorates (Davison, Stening, \& Wai, 1984). This is possible because directors who sit on many boards do so in the company of other directors who also sit on many boards (Conyon \& Muldoon, 2006). Galaskiewicz et al. (1985) found that where the CEO was also a member of the social elite, members of this elite were most likely to be represented on local boards and tended to choose each other to sit on their own boards. This has significant implications because companies obtain information on their respective markets through their other directors (Galaskiewicz et al., 1985).

In Latin American corporations, a few shareholders (mostly family and friends) have significant control rights, and business groups are typically run by the controlling shareholders, rather than by professional managers with little equity ownership (Santiago \& Brown, 2009; Santiago, Brown, \& Baez-Diaz, 2009; Watkins, Van Dijk, \& Spronk, 2006; Salas-Porras, 1992, 2006). Thus, the degree of directors' independence potentially affects minority shareholders' rights because independent directors may not play an important monitoring role, increasing the opportunity for expropriation by majority shareholders (Santiago \& Brown, 2009). Hence, understanding and taking account of interlocked directorates are important to explore especially in emerging economies.

In Mexico there is a legal basis for minority shareholders' rights, but a lack of specific regulations makes it possible for majority shareholders to take advantage of the situation to benefit from minority shareholders (Babatz-Torres, 1997). Given the under-developed markets and democratic institutions in Mexico (Chong \& Lopez de Silanes, 2007; Gomes, 2000), majority shareholders tend to have free reign to occupy top management positions, sit on the board of directors, limit trade in shares, and create business conglomerates (Santiago \& Brown, 2009). Predictably, these issues have led to serious debate about the severe 
consequences of interlocking boards for minority shareholders, especially in concentrated shareholding companies. Interlocking boards give rise to powerful and influential actors in the field, which may prevent independent directors from playing a role in protecting the interests of shareholders, especially minority shareholders, in the context of emerging economies (Salas-Porras, 1992, 1997, 2006). Salas-Porras works have researched Mexican corporate elites and finds that boards of directors have been selected for economic, regional and political interests. Although the corporate board is of particular interest to accounting researchers, few studies have focused on establishing whether there is a pattern of interlocking boards or identifying the most powerful and influential actors and the implications for the corporate governance field in emerging economies including Mexico (Boyd, 1990). Surprisingly, most of the existing research devoted to find out the positive links of independent directors and book value of corporations. This paper departs from this argument and attempt to investigate whether independent directors in a network at all useful to governance mechanisms.

\section{Research method: SNA}

The empirical aim of this paper is to identify the independent directors in a network utilising SNA. The main components of any social network are the actors and their connections. Social networks can be measured and understood in several ways (Tichy et al., 1979; Borgatti \& Foster, 2003; Wang et al., 2009). In this study, we use a two-mode network analysis. A two-mode network is also known as an affiliation network representing the association between two or more sets of nodes, where each set is a different social entity (Wang et al., 2009:12). In our case, one set of nodes represents board members while the other represents corporations, with ties representing directors sitting on company boards. Graphical representations ${ }^{1}$ are used in the paper to capture the visual image of network. 
Knove and Yang (2008:62) observe that a primary use of graph theory in SNA is to identify the important or prominent actors at both the individual and group levels.

One of the main purposes of SNA of interlocking boards is to search for the most influential, important and powerful members and their networks. Centrality is an important conceptual tool for analysing power in social networks. Different positional measures reflect the location of actors in a network. The focus is on the centrality of the board member or the location of the board member in the network. The concept of centrality may be operationalized and measured in a variety of ways. In this study we use Freeman's approach (1979) with two measures of centrality: degree centrality and eigenvalues. These measures of degree centrality for two-mode networks are calculated using UCINET. ${ }^{2}$

In a two-mode network, the degree centrality for a board member is the number of corporations in which he or she sits on a board. The maximum degree for a board member is the total number of corporations (Everett \& Borgatti, 2005). For Freeman (1979), the degree centrality of a network is calculated by counting the number of adjacent links to or from a board member. This is based solely on direct connections and is an appropriate measure to capture power-enhancing behaviours that occur via direct interaction, such as ingratiation and reciprocation (Brass \& Burkhardt, 1993). Another measure of centrality is eigenvalue centrality, an indicator of popularity, indicating the node or board member with the most connections to other nodes or board members who at the same time are connected to other highly-connected board members. In other words, eigenvalue indicates board members with the highest social capital in terms of the possession of a durable network. The eigenvalue also identifies the centre of cohesive groups, and helps to identify those board members with the smallest distance from others in terms of the overall structure of the social network. The highest scores indicate that board members are more central to the main pattern of distances among all board members; lower values indicate that board members are more peripheral. 
The data used in the study consisted of 1,442 internal and external board members of the population of 126 Mexican corporations that traded in the Mexican Stock Market as of January 2011. The population included 19 natural resources companies, 27 industrials, 18 services and goods of non-basic consumption, 24 frequent consumption products, 5 health, 21 financial services, and 12 telecommunications. The sources of data were the corporate annual reports published on the web page of the Mexican Stock Exchange Directory in January 2011. The information provided in the corporate reports includes the names of board members, which are classified as main, substitute, patrimonial, related and independent. In some cases, the annual report also includes biographical information on board members. In the next section, the centrality, power and prestige of interlocking boards in Mexico are demonstrated.

\section{Power, Centrality and Prestige of Board Members}

Power is a fundamental property of social structures, and the location of a board member within the network directly represents his or her access to information. This is relevant if board members are seen as conduits of information between corporations (Everard \& Henry, 2002). In the social network approach, power is inherently relational, and analysis of a network reveals whether an actor is embedded in a relational network. An actor's location in a social network determines his or her prominence and importance in the network. Hence, the measures of centrality (degree centrality and eigenvalue) were calculated using UCINET 6 for the entire population of board members and corporations in the Mexican Stock Market as of January 2011.

In order to visualize the network structure of companies sharing two or more board members, a technique called spring embedding was applied. The rationale is that board members connected by lines are drawn closely together whereas unconnected board members are pushed apart. The spring embedding technique treats the lines of the networks as springs 
with a particular elasticity and strength. The procedure searches for a situation in which the system of springs is stable (De Nooy, 2003). The result is a graphical representation of linkages between board members and corporations. The network is visualized using Netdraw software included in UCINET 6, as shown in Figure 1.

\section{[Insert Figure 1]}

In Figure 1, red bullets represent board members and blue squares represent companies, while lines represent ties between board members and corporations. Figure 1 demonstrates the connectedness of these corporations via board members, suggesting that the corporations employ the same people on their boards. This may reveal little in isolation. Nevertheless, it does suggest that independent directors have little time to focus on protecting shareholders (in the Mexican case, minority shareholders' interests). It also indicates that independent directors may belong to a large social network. This figure shows the interconnections between two or more board members and corporations. Another way in which to visualize the implications of interlocking boards in Mexico is to analyse how corporations are directly linked. We transform the two-mode network (board members and corporations) into a one-mode network for corporations only. This one-mode network draws a direct line between any two companies: if they share two or more board members, this line has a value (multiplicity) of two or more (De Nooy, 2003). We calculate a one-mode network for the companies to establish the relational structure between corporations. Figure 2 shows the interconnections between corporations in the Mexican Stock Market.

\section{[Insert Figure 2]}

In Figure 2, we can see strong links between corporations through board membership. On the left hand side are companies with no connection with other companies in the network. These are isolated companies with no relationship through interlocking boards. Of the 126 
corporations in the Mexican Stock Market, only 17 do not share a board member. This shows a strong structural relationship between companies created by board member linkages in publicly traded corporations in Mexico. In the next section, we examine the location of actors in the network structure of interlocking boards in Mexico. The actors' level of centrality is calculated using Freeman's measures of centrality: degree centrality and eigenvalues.

\subsection{Actors in Networks}

The board of directors is a determinant of corporate governance as it represents the primary decision-making body. Boards of directors are interlinked through a shared director. This is an important characteristic, because the network represents connections between directors and companies and opportunities for face-to-face interaction. A matrix table was constructed of the 1,442 board members and 126 companies traded on the Mexican Stock Exchange. The two-mode data were transformed into one-mode data to carry out analysis using Freeman's measure of centrality. Freeman's output ranks actors from high to low levels of centrality. The results for the top fifteen board members are shown in Table 1.

\section{[Insert Table 1]}

Table 1 shows the (interpersonal) network of boardroom contacts among the top fifteen board members in the Mexican Stock Market. The actor sitting on the highest number of boards is Mr Fernando Ruiz Sahagun, who sits on nine boards of directors. ${ }^{3} \mathrm{He}$ is a public accountant who has sat on the board of GCC as an independent board member since 2006 and works as a consultant in Chavez, Ruiz, Zamarripa and Cia, S.C., a consulting firm. He is a member of the College of Public Accountants of Mexico and has studied fiscal studies at the Universidad Anahuac and the Universidad Panamericana. Mr Alberto Bailleres Gonzalez sits on eight boards of directors. ${ }^{4}$ He holds a bachelor's degree in economics and chairs the governing body of the Mexican Autonomous Institute of Technology (ITAM). Mr Fernando 
Senderos Mestre sits on seven boards ${ }^{5}$ and is in third place in the table. He is 61 years old and holds a bachelor's degree in business administration. He is chairman of Grupo Kuo and Dine, S.A. Mr Valentin Diez Morodo sits on seven boards. ${ }^{6} \mathrm{He}$ is 72 years old and holds a bachelor's degree in business administration. This section has highlighted actors with the highest level of centrality, that is, actors sitting on many boards.

\section{[Insert Table 2]}

In Table 2, eigenvalues provide a different picture of the position of board members in the network structure of interlocking boards in Mexico. Here, we examine the most influential board members in the network structure of interlocking boards in Mexico. The most influential board members are ranked from high to low according to this measure. It shows the fifteen most central actors in terms of the overall structure of the network. Board members with the highest scores are the most central to the pattern of distances among all board members in the global structure of the network. The board member with the highest eigenvalue (0.252) and hence the most central board member in the overall structure of interlocking boards in Mexico is Mr Alberto Bailleres Gonzalez, who is in a structural position from which he can reach those with the smallest distance from others in the global structure of the network. He is better connected to many board members who are also wellconnected to other board members. He is in a very good position within the network to transmit information and to influence other board members in the network structure. The second highest eigenvalue (0.224) is for Mr Arturo Fernandez Perez, who is chancellor of the Mexican Autonomous Institute of Technology (ITAM). The third highest eigenvalue (0.219) is for Mr Tomas Lozano Molina, who holds a Law degree and is public notary and lecturer at the Escuela Libre de Derecho.

The interlocked directorates and powerful actors shown above needs to be understood in the context of under developed capital and democratic institutions and family dominated 
companies in emerging economies. According to Santiago \& Brown (2009), in a typical large Latin American firm, the CEO is usually part of the controlling family; therefore, his or her influence over the board of directors is unlimited. Often the independent directors receive the multiple directorships from the same business group and enjoy material and symbolic benefits come with it (Santiago \& Brown, 2009). Without a doubt, this has consequences for maintaining the independence, transparency and accountability of corporate governance affairs in relation to minority shareholders. The question arises to what extent the independent directors are in a position to curve the power of a CEO of large business group? Alternatively, one could ask a question whether it is in independent director's interests to go against the CEO. Is it more important for independent directors to be in the network and exploit the power they apparently enjoy? These questions are better addressed if further explanations of networks and their inherent features are provided. The next section discusses this.

\section{Social capital and interlocked boards}

This paper mobilizes the notion of social capital advanced by Bourdieu and draws on previous studies in order to provide further explanations of emergence of networks. In order to determine the social capital of board members, we calculated the network of connections which each board member can effectively mobilize. As Bourdieu (1986:249) stated, "The volume of the social capital possessed by a given agent thus depends on the size of the network of connections he can effectively mobilise and on the volume of the capital (economic, cultural or symbolic) possessed in his own right by each of those to whom he is connected". Table 1 shows the name of the board member and the size of the network of connections he/she can mobilize. Furthermore, there is a brief description of the volume of capital (economic, cultural, and symbolic) possessed in their own right by the first two board members in the table. For example, in Table 1 we show the interpersonal network of 
boardroom contacts among the top 15 board members in the Mexican Stock Market, showing that the actor with the highest centrality ranking sits on ten boards of directors. Board members are arranged from high to low levels of "connections" in Table 1. Figure 1 and 2 also revealed board members have created a network structure of social relationships through interlocking boards. For Bourdieu, the network of relationships is "the product of investment strategies" which the independent board member has obtained, individually or collectively, with the objective of establishing or reproducing social relationships "that are directly usable in the short or long term" (Bourdieu, 1986: 249). Board members also have cultural capital demonstrated in the credentials they have (e.g. degree in Stanford) and symbolic capital (e.g. chairman of the chamber of commerce). These capitals (social, cultural and symbolic) further strengthened board members' investment strategies. They will accumulate as much capital (social, cultural and symbolic) as that benefits them.

The networking structure of interlocking boards in Mexico shows the relational practice of board members and the social capital created by interlocking boards. As Portes (1998) has argued, social networks are not a naturally given; on the contrary, they must be constructed by investing in strategies oriented to the institutionalization of relationships between groups as a function of other benefits. The network of configurations demonstrated that board members share a board and related with their peers in the boardroom. Bourdieu observed that individuals' interactions reinforce mutual recognition and acknowledgment as members of a network or group (Lin, 1999). These strategies of investment in social connections are created to perpetuate the governing elite in Mexican corporations. Our empirical results demonstrated that few independent directors dominated majority of the corporations in Mexico.

The main motivation of securing social capital is rooted in material or symbolic profits. Being in a network, as evidenced in earlier figures, provides enormous benefit to 
individual independent directors. According to Bourdieu, the existence of a network of connections ".. is the product of an endless effort at institution, of which institution rites often wrongly described as rites of passage - mark the essential moments and which is necessary in order to produce and reproduce lasting, useful relationships that can secure material or symbolic profits" (Bourdieu, 1986:249). We observe in Figure 1 above, the configuration of the network of connections among board members in the entire population of Mexican corporations traded in the Mexican Stock Market as of January 2011. This is materially useful for individual members. The more they are connected the more capital they can exploit to their advantage. In Table 1 above, we observe the top 15 board members who sit on several boards. And in Table 2 above, we observe the top 15 board members strategically position in the network of directors in Mexican corporations and who can secure material and symbolic profits through the interaction with other board members in the network. Therefore, the process of articulation and the concentration and distribution of links between board members show the positions of the main interlocking actors and the mechanisms that influence the structure of the network in Mexico. Hence, the network structure of interlocking boards in Mexico is the product of a continuous series of exchanges between board members in which recognition is endlessly affirmed and reaffirmed.

What are the implications for corporate governance practices of interlocking directorates created to gain social capital (economic, cultural or symbolic)? Board members in Mexican corporations serve as a means of communication and control for both the individual corporations and the majority shareholders of Mexican corporations through the network of connections they have created and the social capital (economic, cultural or symbolic) which each board member possesses. This raises the question of whether the traditional monitoring role of external directors is present and efficient in Mexico and whether the mere inclusion of an external director on a small board may improve the minority 
shareholders' situation, because the incentives that make external directors work on behalf of minority shareholders, such as the market for corporate control or compensation, are lacking in Latin America.

Santiago \& Brown (2009) have observed that in Mexico, as in most Latin American countries, the misalignment of interests between majority and minority shareholders, rather than divergence between the goals and objectives of management and owner, is at the root of agency problems. Furthermore, corporate governance mechanisms to alleviate agency problems are inefficient or non-existent, while the weak legal environment enhances the potential for agency problems, especially the expropriation of minority shareholders' rights (Santiago \& Brown, 2009). It would not be far from the reality if we can surmise that closelyconnected independent directors in the context of poorly-regulated and under-developed market and political institutions have the potential to lead to lack of transparency and control as found in previous studies (Santiago \& Bown, 2009). These problems have been illustrated in a number of governance scandals in Mexico in recent years. Between 2005 and 2012, several cases relating to corporate governance practices in publicly-listed Mexican corporations have shown the arbitrariness of majority shareholders and how independent board members and internal governance systems appear to have been non-existent or to have failed in these Mexican listed corporations.

The most spectacular failures were the TV AZTECA scandals in 2005, COMERCIAL MEXICANA in 2008 and the Wal-Mart case in 2012. A number of other cases in Mexico are revealed on the SEC webpage. As Jordan and Ahmad (2011) point out, the COMERCIAL MEXICANA case shows the perils of trying to make money on financial instruments rather than focussing on core businesses. This is a case that shows exposure to risk, lack of control, and the ineffectiveness of the audit committee and independent board members. As the chairman of the Mexican Banking and Securities Commission points out: "we have detected 
at least eight where we could infer there were problems with disclosure" (Randewich \& Rojas Mena, 2008). Some of the best-connected independent board members also sat on boards of affected or failing companies. ${ }^{7} \mathrm{We}$ do not wish to claim that these scandals are entirely the result of interlocking boards of directors, but suffice to say they have played their part in failing to protect minority, and in some cases majority, shareholders.

These cases also show that in Mexican corporations independent board members are performing simply a symbolic role. As Bourdieu (1991:126) observes, "the legitimate representative is an object of guaranteed belief, certified as correct. He lives up in reality to his appearance, he really is what everyone believes him to be because his reality - whether priest, teacher or minister - is based not on his personal conviction or pretension ... but rather on the collective belief, guaranteed by the institution and made concrete through qualifications like stripes, uniforms and other attributes." Like Bourdieu's minister or priest, Mexican independent directors seem to playing the same game. Similar to previous studies (Useem, 1984; Granovetter, 1985; Davis, 1996; Mizruchi, 1996) in Mexico, we claim that, by participating in board meetings and sitting on different boards, independent board members are performing ritual practices that do not contribute to the effective monitoring of the company's affairs.

\section{Concluding remarks}

We begin this section by considering the empirical questions set out earlier: namely, whether there is a pattern of interlocking boards, and the positions which actors occupy in the network structure of interlocking boards in Mexico. By applying SNA, this paper examines the connections between Mexican corporations and actors. Using the measures of SNA developed by Freeman (1979), we identify the most powerful and influential actors in the network structure of board members in Mexico. Table 2 describes the eigenvalues of SNA calculated using UCINET, in which board members are arranged from high to low levels of 
"connections". Board members with the greatest number of connections occupy a central position in the network and are able to transmit information and to influence other boards. We also find that, in Mexico, independent board members have created a network structure of social relationships through interlocking boards. For example, Figures 1 and 2 present the network structure of companies sharing two or more board members. For example, in Table 1 we present the (interpersonal) network of boardroom contacts among the top 15 board members in the Mexican Stock Market.

Turning to theoretical questions, why does this network exist and what are the potential implications for corporate governance practices? Drawing on Bourdieu's notion of social capital (1986), we have demonstrated that how and why Mexican corporations have created a durable network of institutionalized relationships. It is clear that the interlocked directorate is a social space where members pursue material and symbolic exchanges. In other words, the creation of a network of interlocking boards in Mexican listed corporations aims to institutionalize a particular corporate governance practice of independent board members who do not monitor the company's affairs. They perform a social ritual tending to consecrate or legitimate an arbitrary boundary to produce and reproduce lasting, useful relationships that can secure material or symbolic profits (Bourdieu, 1986, 1991). This questions the role of independent directors in monitoring and protecting minority shareholders in Mexico and elsewhere in the world.

This study contributes to the study of powerful and influential actors in the network structure of interlocking directorates in emerging economies and Mexico. The SNA of interlocking directorates described in this paper has great potential to contribute to corporate governance research. Firstly, the results suggest that the interlocking directorates and positions of powerful and influential actors may render corporate governance reforms ineffective. It would be reasonable to assume that strong capital markets and the presence of 
institutional investors protect minority interests, even in strongly interlocking directorates. Without strong capital markets and institutional investors, a network of directors may prevent independent directors from acting independently. Further research should be conducted to explore these issues.

Secondly, Bourdieu's notion of social capital is a very useful narrative to understand the network of relationship. Network of independent directors and the durability of the network are clearly understood from motivations of powerful actors derived from material, cultural and symbolic exchanges. Examining the network of directors from a 'social capital' point of view also enable us to understand why the role of independent directors is ineffective. The view of social capital as resources embedded in networks is helpful for understanding why minority shareholders' interests are infringed more in some areas than in others (Uddin and Chowdhury, 2008). This paper denaturalizes mainstream research on independent directors and advance a counter argument that advocates positive links of independent directors and book value of the corporation. Bourdieu's idea of social capital clearly demonstrates that the relational practice of boards is in the interest of board members and their investment strategies only to preserve their benefits. And that is with the consent of majority shareholders, because majority shareholders will invite those board members with substantial social, cultural and symbolic capital, but loyal to them. So, there is a type of complicity. They are like a kind of "club of acquaintances". And the person who exercises power is the majority shareholder, because he/she possesses the most valuable capital (economic capital).

Thirdly, the paper has also opened space for further research especially the use of SNA and understanding power and interests of networks and actors in the network. First, it would be useful to examine cross-cultural differences in networks of directors. It has also been suggested (La Porta, Lopez de Silanes \& Schleifer, 1999, La Porta, Lopez de Silanes, \& 
Vishny, 2000) that corporate governance regulation and implementation vary across countries with different legal systems. One aspect of these differences may be the way in which domestic regulatory regimes have historically been shaped by colonial regimes. French colonies have different regimes from Spanish colonial countries. Countries' links with transnational bodies should also be considered. For example, Mexican corporate governance reforms have been influenced by OECD. More generally, the approach used here could be replicated in other countries.

Fourthly, interlocking boards and networks are not static, and a longitudinal analysis would provide evidence of the network dynamics that affect board activities and the role of independent directors in company affairs. As Gilbert et al. (2011:83) have observed, social networks exhibit temporal dynamics in a number of ways. Instances in the data may appear and disappear over time, whereby different time windows may exhibit different characteristics. For example, a person may change his affiliation with a business organization by joining a different business enterprise and developing new social ties within this new environment. This approach could also be combined with a close focus on key players to track their paths within the network. As we have revealed, several high-profile individuals have important positions in some large corporations. It would be interesting to establish how they reached the key positions in the network. This would, perhaps, unravel the workings of wider corporate governance issues, such as reforms. This study provides a foundation for a deeper understanding of the cosy relationship of directors, family networks and their influence on corporate governance practices in Mexico and elsewhere.

Finally, the network mapped in this paper is based on directors' links. While these are important, other types of network linkages are also important, and the relative effects of different kinds of links on outcomes should be explored, for example the political networks of large corporations, regulatory networks, family networks, and various other informal 
networks. All these influence the protection of shareholders' interests and the overall transparency and accountability of company affairs. As previous studies have indicated, we need to gain a better understanding of the role played in corporate governance failures by family networks with political affiliations, especially in emerging economies (Uddin and Choudhury, 2008). These areas, though important, remain under-investigated and undertheorized.

\footnotetext{
${ }^{1}$ A graph is made up of nodes connected by lines. In this study, corporations and board members are nodes, and connections between them are edges. Another important concept of graph theory is degree, which is the number of edges connected to a node.
}

${ }^{2}$ UCINET is a social network analysis program developed by Steve Borgatti, Martin Everett and Lin Freeman. As Knove and Yang (2008:2) observe, "UCINET with its continually updated versions is probably the most popular and extensively used software package, providing comprehensive solutions and implementation of many network methods".

${ }^{3}$ Fernando Ruiz Sahagun is a member of the board of directors of the following companies: Kimberly Clark, Modelo Group, Mexichem, San Luis Corporation, Grupo Mexico, Empresas ICA, Grupo Financiero SANTANDER, Grupo POCHTECA, Fresnillo, the Mexican Stock Market, Arcelor Mittal Lazaro Cardenas, and INDEVAL. He is chairman of the Fiscal Committee of the Mexican Coordinated Council, and he represents the Mexican Council of Businessmen in the Secretary of Fiscal and Public Credit of Mexico.

${ }^{4}$ Alberto Bailleres Gonzalez is a member of the board of directors of the following companies: Grupo KUO, Industrias Penoles, Grupo Nacional Provincial, GNP Pensiones, Profuturo, Valores Mexicanos, Casa de Bolsa, Grupo Palacio de Hierro, FEMSA, Grupo Televisa and Grupo BBVA.

${ }^{5}$ Fernando Senderos Mestre is board member of Industrias Peñoles, Grupo Carso, S.A., Kimberly Clark, Grupo Televisa, Grupo Desc, GNP, Grupo Carso and of the Mexican Council of Businessmen.

${ }^{6}$ Valentin Diez Morodo is an independent board member in Kimberly-Clark de Mexico, Grupo Financier Banamex, Grupo Kuo, Alfa, Grupo Dine, Grupo Mexico, Bodegas Vega Sicilia, Acciones y Valores de Mexico, Zara Mexico, Grupo Aeromexico, Citigroup, Inc, OHL Mexico, Telefonica Mexico and Instituto de Empresa, Madrid.

${ }^{7}$ This is also the case for the ALFA group, in which we detected Mr Claudio X Gonzalez Laporte, who sits on eight boards and is ranked 4th in degree centrality (see Table 1), Mr Valentin Diez Morado, who sits on seven boards and is ranked 5th in degree centrality, and Mr Enrique Castillo Sanchez Mejorada, who sits on seven boards and is ranked 10th in degree centrality. All of these were board members of ALFA group during the Mexican derivatives crisis in 2008.

\section{References}

Allen, M. P. (1974). The structure of interorganizational elite cooptation: Interlocking corporate directorates, American Sociological Review, 39(3): 393-406. 
Au Kevi, Mike W. Peng and Dennis Wang (2000), Interlocking directorates, firm strategy, and performance in Hong Kong: Towards a research agenda, Asian Pacific Journal of Management, 17: 29-47.

Babatz-Torres, G. (1997). Ownership structure, capital structure, and investment in emerging markets: The case of Mexico. Unpublished doctoral dissertation, Harvard University, Cambridge, MA.

Berglof, E. \& Claessens, S. (2006). Enforcement and good corporate governance in developing countries and transition economies, The World Bank Research Observer, 21(1): $121-50$.

Bonacich, P. (1991). Simultaneous group and individual centralities, Social Networks, 13(2): 155-168.

Borgatti, S.P. \& Everett, M.G. (1997). Network analysis of 2-mode data, Social Networks, 19(3): 243-269.

Borgatti, S. P. \& Foster, P. C. (2003). The network paradigm in organizational research: A review and typology, Journal of Management, 29(6): 991-1013.

Bourdieu, P. (1986). The forms of capital. In J. G. Richardson (Ed.), Handbook of Theory and Research for the Sociology of Education: 241-258. New York: Greenwood Press.

Bourdieu, P. (1990). The logic of practice. Malden, MA: Polity Press.

Bourdieu, P. (1991). Rites of institution. In Language and Symbolic Power: 115-126. Cambridge: Harvard University Press.

Bourdieu, P. (2000). Pascalian meditations. Malden, MA: Polity Press.

Bourdieu, P. \& Wacquant, L. J. D. (1992). An invitation to reflexive sociology. Chicago: University of Chicago Press.

Boyd, B. (1990). Corporate linkages and organizational environment: A test of the resource dependence model, Strategic Management Journal, 11: 419-430.

Brandeis, L. (1914). Other people's money and how the bankers use it. New York, NY: Stokes. 
Brass, D. J. \& Burkhardt, M. E. (1993). Centrality and power in organizations. In N. Nohria \& R.G. Eccles (Eds.), Networks and organizations: Theory and Practice. 191-215, Boston, MA: Harvard Business School Press.

Burt, R. (1983). Corporate profits and cooptation. New York: Academic Press.

Chapman, C. S. (1998). Accountants in organisational networks, Accounting Organizations and Society, 23(8): 737-766.

Chong, A \& Lopez de Silanes, F. (2007). Corporate governance in Latin America. In A. Chong \& F. Lopez de Silanes (Eds.), Investor protection and corporate governance: Firmlevel evidence across Latin America. 1-83, Stanford: Stanford University Press.

Chua, W.F. \& Poullaos, C. (1993), Rethinking the profession-state dynamic: The case of the victorian charter attempt: 1885-1906, Accounting, Organizations and Society, 18(7/8): 691728

Conyon M. J. \& Muldoon M. R. (2006). The small world of corporate boards, Journal of Business, Finance and Accounting, 33 (9 \&10): 1321-1343.

Davison, A. G., Stening, B. W. \& Wan, T.W. (1984). Auditor concentration and the impact of interlocking directorates, Journal of Accounting Research, 22(1): 313-317.

Davis, G. F. (1996). The significance of board interlocks for corporate governance, Corporate Governance, 4: 154-159.

De Nooy, W. (2003). Fields and networks: correspondence analysis and social network analysis in the framework of field theory, Poetics, 31: 305-327.

Dyck, A. \& Zingales, L. (2002). Private benefits of control: An international comparison, Discussion paper No. 3177. Centre For Economic Policy Research. available online at: http://papers.ssrn.com/abstract=301200. Accessed: 12 June, 2010.

Everard, A. \& Henry, R. (2002). A social network analysis of interlocked directorates in electronic commerce firms, Electronic Commerce Research and Applications, 1: 225-234.

Everett, M. G. \& Borgatti S. P. (2005). Extending centrality. In P.J. Carrington, J. Scott, \& S. Wasserman (Eds.), Models and methods in social network analysis. 57-75, Cambridge: Cambridge University Press. 
Fama, E. F. \& Jensen, M. C. (1983). Separation of ownership and control, Journal of Law and Economics, 26(2): 301-25.

Fombrun, C. (1982). Strategies for network research in organizations, Academy of Management Research, 7(2): 280-291.

Freeman, L. C. (1979). Centrality in social networks conceptual clarification, Social Networks, 1: 215-239.

Freeman, L. C. (2004). The development of social network analysis: A study in the sociology of science. Vancouver: Empirical Press.

Galaskiewicz, J., Wasserman, S., Raushenbach, B., Bielefeld, W., \& Mulaney. P. (1985). The influence of corporate power: Social status and market position on corporate interlocks in a regional network, Social Forces, 64(2): 403-43.

Gerlach, M. (1992). Alliance capitalism: The social organization of Japanese business. Berkeley: University of California Press.

Gilbert, F., Simonetto, P., Zaidi, F., Jourdan, F., \& Bourqui, R. (2011). Communities and hierarchical structures in dynamic social networks: Analysis and visualisation, Social Network Analysis and Mining, 1: 83-95.

Gomes, A. (2000). Going public without governance: Managerial reputation effects, Journal of Finance, 55(2): 615-646.

Granovetter, M. (1985). Economic action and social structure: The problem of embeddedness, American Journal of Sociology, 91: 481-93.

Heemskerk, E. M. \& Schnyder, G. (2008). Small states, international pressures and interlocking directorates: The cases of Switzerland and the Netherlands, European Management Review, 5: 41-54.

Hilferding, R. (1910). Finance Capital. London: Routledge.

Hooper, T. Tsamenyi M., Uddin, S. \& Wickramsinghe, D. (2009). Management accounting in less developed countries: what we know and needs knowing, Accounting, Auditing and Accountability Journal, 22(3): 469-514. 
Huse, M. (2005). Accountability and creating accountability: A framework for exploring behavioral perspectives of corporate governance, British Journal of Management, 16: 565579.

Ionescu, L. (2011), The financial crisis as a failure of corporate governance, Economics, Management and Financial Markets, 6(2): 827-832.

Jeidels, O. (1905). Das Verhaltnis der deutschen Grosbanken zur Industrie. Leipzig: Duncker und Humblot.

Johnson, J., Daily, C., \& Ellstrand, A. (1996). Boards of directors: A review and research agenda, Journal of Management, 22(3): 409-438.

Jordan M. \& Rahmena A. (2011). Derivatives at Controladora Comercial Mexicana (CCM), Instituto de Estudios Superiores de la Empresa, F-859-E, November.

Kirkpatrick, G. (2009). Corporate Governance lessons from the financial crisis, OECD Journal: Financial Market Trends, 61-87.

Knove D. \& Yang, S. (2008). Social network analysis, second edition, London: Sage Publications.

Kotz, D. M. (1978). Bank control of large corporations in the United States, Berkeley: University of California Press.

Krackhardt, D. (1992). The strength of strong ties: The importance of philos in organizations. In N. Nohria \& R.G. Eccles (Eds.), Networks and organizations: Structure, form and action: 216-239, Boston: Harvard Business School Press.

La Porta, R., Lopez de Silanes, F., \& Shleifer, A. (1999). Corporate ownership around the world, Journal of Finance, 54(2): 471-517.

La Porta, R., Lopez-de-Silanes, F., \& Vishny, R. (2000). Investor protection and corporate governance, Journal of Financial Economics, 58: 3-29.

Lakon, C. M., Godette, D. C., \& Hipp, J. R. (2008). Network-based approaches for measuring social capital. In I. Kawachi, S. V. Subramanian, \& D. Kim (Eds.), Social capital and health. New York: Springer Science. 
Lim, M. H. \& Porpora, V. (1987). Stock ownership and interlocking directorates among Malaysia's top corporations, Critical Sociology, 14: 77-101.

Lin, N. (1999). Building a network theory of social capital, Connections, 22(1): 28- 51.

Lin, N. (2001). Social capital: A theory of social structure and action. Cambridge: Cambridge University Press.

Lorsch, J. W. \& MacIver, E. (1985). Pawns or potentates: The reality of america's corporate boards, Boston: Harvard University Press.

Mac Canna Leo, Niamh Brennan and Eleanor O’Higgins (1999), National Networks of Corporate Power: An Irish perspective, Journal of Management and Governance, 2: 355-377.

Mariolis, P. \& Jones, M. H. (1982). Centrality in corporate interlock networks: Reliability and stability, Administrative Science Quarterly, 27(4): 571-585.

Martinson, O. B. \& Campbell, G. R. (1979). Social network analysis: Suggested applications to economic control, Journal of Economic Issues, 13(2): 471-487.

Mintz, B. \& Schwartz, M. (1981). Interlocking directorates and interest group formation, American Sociological Review, 46(6): 851-869.

Mizruchi, M. S. \& Bunting, D. (1981). Influence in corporate networks: An examination of four measures, Administrative Science Quarterly, 26: 475-489.

Mizruchi, M. S. \& Galaskiewicz, J. (1993). Networks of interorganizational relations, Sociological Methods and Research, 22: 46-70.

Mizruchi, M.S. (1996). What do interlocks do?: An analysis, critique and assestment of research on interlocks directorates, Annual Review of Sociology, 22: 271-298.

National Resources Committee, (1939). The structure of the American economy, part 1: Basic characteristics, Washington, D.C.: U.S. Government Printing Office.

Ong, C., Wan, D., \& Ong, K. (2003). An exploratory study on interlocking directorates in listed firms in Singapore, Corporate Governance: An International Review, 11(4): 323-333. 
Orsten, M. (1984). Interlocking directorates in Canada: Intercorporate or class alliance? Administrative Science Quarterly, 1(2): 210-231.

Pederson, T. \& Thomsen, S. (1997). European patterns of corporate ownership: A twelvecountry study, Journal of International Business Studies, 28: 749-758.

Peng, M. W., Au, K. Y. \& Wang, D. Y. L. (2001). Interlocking directorates as corporate governance in third world multinationals: Theory and evidence from Thailand, Asia Pacific Journal of Management, 18: 161-181.

Perlo, V. (1957). The empire of high finance. New York: International Publishers.

Pfeffer, J. \& Salanick, G. R. (1978). The external control of organizations: A resource dependence perspective. New York, NY: Harper Row.

Portes, A. (1998). Social capital: Its origins and applications in modern sociology, Annual Review of Sociology, 22: 1-24.

Portes, A. \& Landolt, P. (2000). Social capital: Promise and pitfalls of its role in development, Journal of Latin American Studies, 32(2): 529-547.

Randewich N. \& Rojas-Mena, L. (2008). Reuters: UPDATE 2-Mexico investigates bank's risky derivatives sales. Available at: http://www.reuters.com/article/2008/12/5/mexicoregulator-idUSN1551595920081215.

Richardson, A. J. (2009). Regulatory networks for accounting and auditing standards: A social network analysis of Canadian and international standard-setting, Accounting Organizations and Society, 34(5):571-588.

Richardson, R.J. (1987). Directorship interlocks and corporate profitability, Administrative Science Quarterly, 32(3): 367-386

Salas-Porras, A. (1992). Globalización y proceso corporativo de los grandes grupos económicos en México, Revista Mexicana de Sociologia, 54(2): 133-162.

Salas-Porras, A. (1997). The Mexican business class and the process of globalization: Trends and counter-trends, Unpublished doctoral dissertation, London School of Economics, University of London, London, UK. 
Salas-Porras A. (2006). Fuerzas centrípetas y centrífugas en la red corporativa mexicana (1981-2001), Revista Mexicana de Sociología, 68(2): 331-375.

Santiago, C. M., Brown, C. J. \& Baez-Diaz, A. (2009). Prácticas de gobierno corporativo en América Latina, Academia Revista Latinoamericana de Administración, 43: 26-40.

Santiago, M. \& Brown, C. J. (2009). An empirical analysis of Latin American board of directors and minority shareholders' rights, Forum Empresarial, 14(2): 1-18.

Scott, J. (2011). Social network analysis: Developments, advances and prospects, Social Network Analysis and Mining, 1: 21-26.

SEC (2005). SEC charges TV Azteca and its chairman - Ricardo Salinas Pliego - with fraudulent scheme to conceal Salinas' $\$ 109$ million windfall through related party transactions. US Securities and Exchange Commission. Available at: www.sec.gov/news/press/2005-1.htm.

Shankar, M. A. \& Bhattacharya, S. (2011), The linkage between financial crisis and corporate governance: A literature review, The IUP journal of corporate governance, $\mathrm{X}(3)$ : 71-84.

Silva, F., Majluf, N. \& Paredes, R. D. (2006). Family ties, interlocking directorates and performance of business groups in emerging countries: The case of Chile, Journal of Business Research, 59(3): 315-321.

Stiles, P. \& Taylor, B. (2001). Boards at work: How directors view their roles and responsibilities. Oxford: Oxford University Press.

Stinchcombe, A. L. (1990). Information and organizations. Los Angeles, CA: University of California Press.

Stokman, F. and F.W. Wasseur (1985), National Networks in 1976: A structural comparison, in F. Stokman, R. Ziegler and J. Scott (Eds.), Networks of corporate power: A comparative analysis of ten countries. London: Polity Press, 20-44.

Stokman, F., Ziegler, R. and Scott, J. (Eds.) (1985). Networks of corporate power: A comparative analysis of ten countries. London: Polity Press.

Tichy. N. M., Tishman, M. L., \& Fombrun, C. (1979). Social network analysis for organizations, The Academy of Management Review, 4(4): 507-519. 
Uddin, S. \& Choudhury, J. (2008). Rationality, traditionalism and the state of corporate governance mechanisms: Illustrations from a less developed country, Accounting, Auditing and Accountability Journal, 21(7): 1026-105.

Useem, M. (1984). The inner circle: Large corporations and the rise of business political activity in the US and the UK. New York: Oxford University Press.

Wang, P., Sharpe, K., Robins, G. L., \& Pattison, P. E. (2009). Exponential random graph (p*) models for affiliation networks, Social Networks, 31: 12-25.

Wasserman, S. \& Faust, K. (1994). Social network analysis: Methods and applications. Cambridge, UK: Cambridge University Press.

Watkins, K., Van Dijk, D. \& Spronk, J. (2006). Corporate governance and performance during the aftermath of the 1994 Mexican crisis, EconoQuantum, 2(2): 39-55.

Wearing, R. T. (2005). Cases in corporate governance. London: Sage Publications.

White, H. C., Boorman, S. A., \& Breiger, R.L. (1976). Social structure from multiple networks I, American Journal of Sociology, 81: 730-780.

Zattoni, A. \& Cuomo, F. (2010). How independent, competent and incentivized should nonexecutive directors be? An empirical investigation of good governance codes, British Journal of Management, 21(1): 63-79. 